\title{
Longer Failure-Free Survival Interval of Epstein-Barr Virus-Associated Classical Hodgkin's Lymphoma: A Single-Institution Study
}

Jens Krugmann, M.D., Alexandar Tzankov, M.D., Andreas Gschwendtner, M.D., Martina Fischhofer, Richard Greil, M.D., Falko Fend, M.D., Stephan Dirnhofer, M.D.

Institute of Pathology (JK, AT, AG) and Department of Internal Medicine, Division of Hematology and Oncology (MF, RG), University of Innsbruck, Austria; Institute of Pathology, Technical University of Munich, Munich, Germany (FF); and Institute of Pathology, University of Basel, Basel, Switzerland (SD)

We analyzed Epstein-Barr virus association in classical Hodgkin's lymphoma from a single center in Austria with special emphasis on the latent membrane protein1 gene configuration and clinical outcome. All 119 (65 male, 54 female) patients were treated from 1974 to 1999 in the Division of Hematology and Oncology at the Department of Internal Medicine, University of Innsbruck, Austria. The mean follow-up time was 122 months (range, 3-333 mo). Epstein-Barr virus was examined by latent membrane protein 1 immunohistochemistry and by in situ hybridization for Epstein-Barr virus-encoded early ribonuclein acid transcripts. For assessment of the Epstein-Barr virus subtype (A/B) and latent membrane protein1 gene configuration, the polymerase chain reaction was employed. Fifty-four reactive tonsils were used as the control population. These results as well as clinical parameters such as age, gender, tumor stage, risk factors, and B symptoms were correlated with failure-free and overall survival. Latent membrane protein1 was detected in 31/119 (26\%) classical Hodgkin's lymphoma, and Epstein-Barr virus subtyping was successful in 19 of the 31 virus-infected classical Hodgkin's lymphoma cases, as well as in $\mathbf{2 8}$ of $\mathbf{5 4}$ reactive tonsils. Subtype A was observed in all classical Hodgkin's lymphoma patients and in 26/28 (93\%) tonsils. The 30-base pair latent membrane protein1 gene deletion was found in only 4/31 (13\%) Epstein-Barr virusassociated classical Hodgkin's lymphoma as well as in $20 / 54(37 \%)$ reactive tonsils. Patients with

\footnotetext{
Copyright (C) 2003 by The United States and Canadian Academy of Pathology, Inc.

VOL. 16, NO. 6, P. 566, 2003 Printed in the U.S.A.

Date of acceptance: February 21, 2003.

This study was supported by the Austrian Nationalbank, Project 5621, and by the Krebshilfe Tirol.

Address reprint requests to: Stephan Dirnhofer, M.D., Institute of Pathology, University of Basel, Schoenbeinstrasse 40, CH-4031 Basel, Switzer land; fax: +41-61-2653194; e-mail: sdirnhofer@uhbs.ch.

DOI: $10.1097 / 01 . M P .0000071843 .09960 . B F$
}

Epstein-Barr virus-associated classical Hodgkin's lymphoma showed a significantly longer mean time to first relapse of 99 months, as compared with 49 months for the Epstein-Barr virus-negative cases $(P$ $<.02$ ), and were more frequent in those aged $>45$ years $(P<.04)$. Epstein-Barr virus-associated classical Hodgkin's lymphoma were predominantly of the mixed-cellularity subtype and occurred more frequently in male patients, in patients with Stage III and IV, and in patients with B symptoms as well as risk factors. However, overall survival did not correlate with Epstein-Barr virus association. The 30-base pair latent membrane protein1 gene deletion had no influence on overall survival and failure-free survival time. Although the number of patients with this specific mutation was low, it further shows that an increased oncogenic potential of the latent membrane protein1 deletion variant is unlikely. This large single-center study demonstrates a low prevalence of Epstein-Barr virus positivity in classical Hodgkin's lymphoma in western Europe. In accordance with results of similar studies, the presence of Epstein-Barr virus has a beneficial effect on the length of failure-free survival despite the higher frequency of risk factors such as higher tumor stage or advanced age.

KEY WORDS: Classical Hodgkin's lymphoma, EBV subtypes A and B, Epstein-Barr virus (EBV), Latent membrane protein1 gene, Survival analysis.

Mod Pathol 2003;16(6):566-573

Epidemiological and molecular findings suggest that Epstein-Barr virus (EBV) directly contributes to the pathogenesis of a variable proportion of classical Hodgkin's lymphoma cases. The frequency of EBV association of classical Hodgkin's lymphoma depends on age, geographic location, socioeconomic status, and histological subtype (1-15). The prognostic relevance of EBV infection in classical 
Hodgkin's lymphoma is still under investigation. EBV-associated classical Hodgkin's lymphoma are supposed to occur in advanced tumor stage (Stages III and IV) and in more aggressive histological subtypes $(3,4,16,17)$. Whereas earlier studies failed to demonstrate an effect of EBV association on outcome in classical Hodgkin's lymphoma (16, 18-24), more recent surveys involving larger number of patients demonstrated a beneficial effect on failurefree survival and relapse $(13,17,18,22)$.

Little is known about the influence of EBV strains and latent membrane proteinl gene variants on the clinical behavior of classical Hodgkin's lymphoma. The two EBV subtypes A and B encode nine latently expressed genes, i.e., six nuclear antigens (EBV nuclear antigen 1, 2, 3A, 3B, 3C, and LP) and three membrane proteins (latent membrane protein1, latent membrane protein $2 \mathrm{a}$, and latent membrane protein2b) (25). Latent membrane protein 1 is an established viral oncogene that is involved in the activation and transformation of human B-lymphocytes (26). Interestingly, the presence of a characteristic C-terminal 30-base pair in-frame deletion of the latent membrane protein1 gene has been described in EBV-associated carcinomas and classical Hodgkin's lymphoma (27). Initially, a higher tumorigenic potential and an association with an aggressive histology was described for this variant (27). However, similar rates of the EBV latent membrane protein1 deletion variant in both neoplastic and reactive lymphoid tissue from the same geographic area have been recently reported, thereby challenging the concept of an increased tumorigenicity (27-29). Nevertheless, clinical data about the potential prognostic impact of the latent membrane protein1 gene deletion variant and EBV subtype are still largely lacking.

We previously reported a study of Mexican classical Hodgkin's lymphoma in which we found an unexpectedly high prevalence of the latent membrane protein1 deletion in both reactive lymphoid tissues as well as classical Hodgkin's lymphoma ( $59 \%$ versus $80 \%$, respectively). We concluded that this high percentage of the deletion variant simply reflects the distribution of EBV genotypes in the investigated population and not a tumor-specific gene variant (6).

On the background of these somewhat controversial findings, we aimed to examine the frequency and prognostic importance of EBV positivity as well as the impact of EBV variants in a large, welldocumented series of classical Hodgkin's lymphoma patients treated at a single center in Austria.

\section{MATERIALS AND METHODS}

\section{Cases}

We analyzed 132 formalin-fixed, paraffinembedded cases of classical Hodgkin's lymphoma from the files of the Institute of Pathology, University of Innsbruck, diagnosed between 1974 and 1999. All cases were reclassified according to the updated World Health Organization classification by two of the authors (JK, SD) by reviewing hematoxylin and eosinstained slides and immunohistochemical stains (30). We excluded six cases of nodular lymphocytepredominant Hodgkin's lymphoma, three cases of diffuse large B-cell lymphoma of the primary mediastinal subtype, and two cases of anaplastic large T-cell lymphoma. Two cases of classical Hodgkin's lymphoma were excluded because of insufficient paraffin material. In 8 of the remaining 119 cases, the histological subtype was changed. In addition, a total of 54 hyperplastic tonsils (33 male and 21 female patients; age range, 4 to $88 \mathrm{y}$; mean, 27 y) were analyzed for control purposes. Clinical data were obtained by reviewing the charts and contacting the treating physicians.

\section{In Situ Hybridization}

In situ hybridization was done on deparaffinized and dehydrated serial sections. Fluorescein-labeled oligonucleotides complementary to portions of the EBV-encoded early ribonuclein acid transcripts $1 / 2$ were used for hybridization at $42^{\circ} \mathrm{C}$, as described previously (31). After overnight incubation, the sections were washed with Tris/HCL-buffer, detected with the alkaline phosphatase/antialkaline phosphatase technique, and stained with Fast Red (Sigma, Vienna, Austria). A fluorescein-labeled poly-d (T) probe (Biogenex, San Ramon, CA) was used to assess mRNA integrity.

\section{Immunohistochemistry}

Immunohistochemical analysis was performed as described previously (6). Different pretreatment procedures used for antigen retrieval, as well as the primary antibodies employed, are listed in Table 1.

TABLE 1. Summary of Antibodies Used in this Study

\begin{tabular}{llll}
\hline Antibody & Clone & Source & Pretreatment \\
CD15 & Leu M1 & Dakopatts, Copenhagen, DK & Wet autoclave \\
CD20 & L26 & Dakopatts & Microwave \\
CD30 & Ber H2 & Dakopatts & Wet autoclave \\
LMP1 of EBV & (CS 1-4) & Dakopatts & Pronase \\
\hline
\end{tabular}


DNA Extraction, Polymerase Chain Reaction, and Southern Blot Hybridization for the Latent Membrane Protein 1 Gene Deletion

DNA extraction from paraffin-embedded material and polymerase chain reaction (PCR) analysis were performed as described previously (32). DNA integrity was assessed by amplification of a $268-$ base pair fragment of the $\beta$-globin gene (33). PCR analysis of the latent membrane protein1 gene deletion was done using two oligonucleotide primers flanking the site of the characteristic 30-base pair, rendering a 161-base pair product for the wild-type sequence and a 131-base pair fragment for the deletion variant, respectively (32).

The results were confirmed by Southern blot hybridization using a digoxigenin-labeled internal probe specific for the deleted segment, thus hybridizing only against the wild-type latent membrane protein 1 gene and not the deleted latent membrane protein 1 gene, as well as an oligonucleotide specific for a sequence flanking the deleted segment, therefore binding to both latent membrane protein1 gene variants.

\section{EBV Genotyping}

Identification of Type A and Type B strains of EBV was accomplished with oligonucleotide primers flanking a region of the Epstein-Barr nuclear antigen2 gene, as reported previously $(6,34)$. The shorter 168-base pair fragment corresponded to Subtype A, and the longer 184-base pair fragment, to Subtype B.

\section{Statistical Evaluation}

Data registration and the statistical analysis were done using STATISTIKA software package (Microsoft Corp., Redmond, WA). The cumulative patient survival was estimated according to the Kaplan-Meier method (35). The survival curves were compared by the log-rank test. For correlation analysis, we used Spearman rank test and the Mann-Whitney $U$ test (36). Statistical significance was defined by $P<.05$.

\section{RESULTS}

\section{Clinical Data}

The study group consisted of 65 (55\%) male and $54(45 \%)$ female patients. The mean age for men was 40.4 years (range, $14-83 \mathrm{y}$ ) and for women, 34.3 years (range, 16-77 y). Eighty-six of the 119 patients (72\%) were younger than 45 years of age. The median follow-up time was 122 months (range, 3-333 mo). The clinical stage and the occurrence of $B$ symptoms were known in 110 patients, and for 106 patients, we had information about the occurrence of risk factors. Data about the treatment were available for 108 patients. Fifty-four of the patients were treated with combined chemotherapy and radiotherapy; 30 patients, only by chemotherapy; and 24 patients, only with radiotherapy.

\section{Histopathological and Immunohistochemical Findings}

Nodular sclerosis was the most common subtype with $70(59 \%)$ cases, followed by $39(31 \%)$ cases of mixed-cellularity subtype, $7(7 \%)$ cases of lymphocyte-predominant subtype, and 3 (3\%) cases of lymphocyte-depleted subtype (Fig. 1A). All 119 classical Hodgkin's lymphoma expressed CD30, and 108/119 (91\%) expressed CD15. EBV positivity was detected by latent membrane protein $1 \mathrm{immu-}$ noreactivity in 31/119 (26\%) cases (Fig. 1B). The four histological subtypes showed an increase in latent membrane protein 1 positivity from $0 / 7$ of the lymphocyte-predominant subtype, 15/70 (21\%) of the nodular sclerosis subtype, 1/3 (33\%) of the lymphocyte-depleted subtype, and 15/39 (38\%) of the mixed-cellularity subtype.

\section{In Situ Hybridization}

Expression of EBV-encoded early RNA transcripts 1/2 was seen in Hodgkin and Reed-Sternberg cells of all latent membrane proteinl-positive classical Hodgkin's lymphoma by in situ hybridization. The nuclei showed a strong positive signal in virtually all of the neoplastic cells. None of the latent membrane protein1-negative cases was positive by EBVencoded early RNA transcripts in the neoplastic cells (Table 2).

\section{EBV Genotyping}

Latent membrane protein1 gene-derived PCR products were obtained in all latent membrane protein1-positive classical Hodgkin's lymphoma. Only 4 of 31 (13\%) latent membrane protein1-positive cases contained the latent membrane protein 1 deletion variant (Fig. 2, Table 2). The remaining 27 (87\%) cases showed the wild-type latent membrane protein1 gene configuration. Interestingly, we also detected the 30-base pair gene deletion in 20 of 54 (37\%) reactive hyperplastic tonsils.

PCR analysis of the EBV nuclear antigen2 gene sequence to determine the subtype of EBV was done in cases of classical Hodgkin's lymphoma that were amplifiable for the latent membrane protein 1 gene and in the reactive tonsils. It was successful in 19/31 (61\%) classical Hodgkin's lymphoma cases, all of which showed the specific 168-base pair fragment of Subtype A (100\%). In the hyperplastic lymphoid tissue of 28 tonsils, Type A was detected in 26 (93\%) cases, and Type B, in 2 (7\%) cases. 


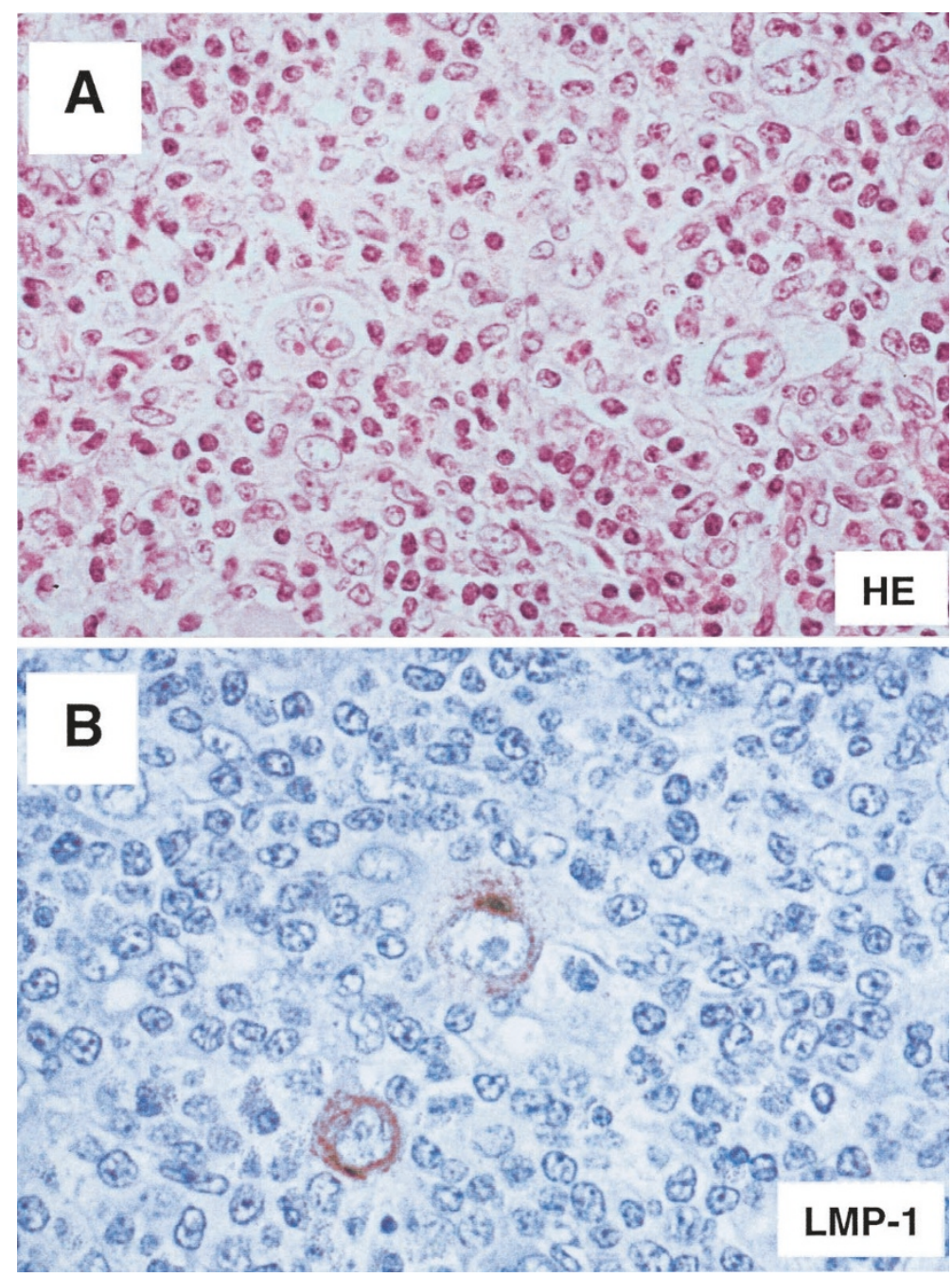

FIGURE 1. A, H\&E stain of classical Hodgkin's lymphoma, mixed-cellularity type. Typical Hodgkin and Reed-Sternberg cells surrounded by reactive lymphoid cells (original magnification, 20×). B, latent membrane proteinl immunostain of classical Hodgkin's lymphoma. Hodgkin and Reed-Sternberg cells show the typical membranous staining pattern (original magnification, $40 \times$ ).

TABLE 2. Immunohistochemical and Molecular Findings

\begin{tabular}{|c|c|c|c|c|c|c|c|c|c|}
\hline \multirow[b]{2}{*}{ Subtype } & \multirow[b]{2}{*}{$n$} & \multicolumn{2}{|c|}{ Sex } & \multicolumn{4}{|c|}{$\%$ Number } & \multicolumn{2}{|c|}{ LMP1 genotype } \\
\hline & & M & $\mathrm{F}$ & CD15 & CD30 & LMP1 & EBER-ISH & $\begin{array}{l}\text { Wild } \\
\text { Type }\end{array}$ & del \\
\hline NS & 62 & 31 & 31 & $85(53 / 62)$ & $100(62 / 62)$ & $23(14 / 62)$ & $24(14 / 58)$ & 13 & 1 \\
\hline NSII & 8 & 5 & 3 & $100(8 / 8)$ & $100(8 / 8)$ & $12(1 / 8)$ & $17(1 / 6)$ & 0 & 1 \\
\hline MC & 39 & 26 & 13 & $97(38 / 39)$ & $100(39 / 39)$ & $38(15 / 39)$ & $44(15 / 34)$ & 13 & 2 \\
\hline LP & 7 & 2 & 5 & $100(7 / 7)$ & $100(7 / 7)$ & $0(0 / 7)$ & $0(0 / 6)$ & 0 & 0 \\
\hline LD & 3 & 1 & 2 & $67(2 / 3)$ & $100(3 / 3)$ & $33(1 / 3)$ & $33(1 / 3)$ & 1 & 0 \\
\hline Total & 119 & 65 & 54 & $91(108 / 119)$ & $100(119 / 119)$ & $26(31 / 119)$ & $30(31 / 107)$ & 27 & 4 \\
\hline
\end{tabular}

EBER = Epstein-Barr encoded early RNA transcripts; ISH = in situ hybridization; LMP = latent membrane protein; IHC = immunohistochemistry; NS = nodular sclerosis; $\mathrm{MC}=$ mixed cellularity; $\mathrm{LP}=$ lymphocyte predominant; $\mathrm{LD}=$ lymphocyte depletion; del, deleted.

\section{Clinical Data and Survival Analysis}

In our study, we found an increased occurrence of EBV-positive cases in male patients, in advanced stage disease (Ann-Arbor III and IV), and in patients with B symptoms and risk factors (mediastinal bulk, extranodal involvement, increased erythrocyte sedimentation rate, involvement of three or more lymph node regions). None of these parameters reached statistical significance compared with the case of EBV-negative classical Hodgkin's lymphoma (Table 3). Patients older than 45 years showed a significant increase in EBV positivity, from 21 to $39 \%(P<.04$; Table 3$)$.

A recurrence of the disease was observed in 32/ 119 (27\%, 20 male, 12 female) patients at approximately equal rates in EBV-positive and -negative 


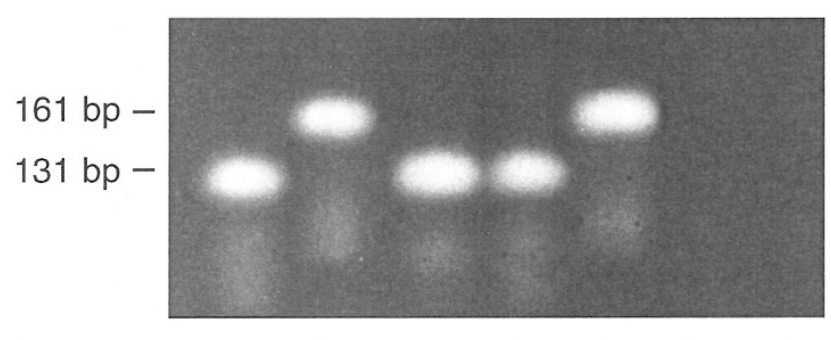

A $\quad$ B $\quad$ C $\quad$ D $\quad E \quad F \quad G$

FIGURE 2. PCR analysis for the 30-base pair latent membrane protein1 gene deletion in Hodgkin's lymphoma. In Lanes $\boldsymbol{B}$ and $\boldsymbol{E}$, a 161-base pair fragment was detected, corresponding to the full-length (wild-type) latent membrane protein1 gene, whereas in Lanes $\boldsymbol{A}, \boldsymbol{C}$, and $D$, a 131-base pair fragment was detected that corresponds to the $30-$ base pair latent membrane protein 1 gene deletion. Lanes $\boldsymbol{F}$ and $\boldsymbol{G}$ were negative controls (no DNA).

cases. Seven (23\%) recurrences occurred in the latent membrane protein1-positive classical Hodgkin's lymphoma, and 25 (28\%), in the latent membrane protein1-negative cases $(P<.53)$. Twenty-three patients experienced a recurrence once; 5 patients, twice; 3 patients, three times; and 1 patient, five times. The mean time to the first recurrence was 49 months in latent membrane protein1-negative classical Hodgkin's lymphoma and was 99 months in latent membrane protein1-positive cases $(P<.02$; Fig. 3$)$. In a multivariate analysis, EBV association was not recognized as an independent prognostic factor for failure-free survival.

Twenty-five (21\%) of 119 patients died during the follow-up period. Seven patients died from tumor progression, and six died because of the development of a second malignancy (carcinoma of the lung in 2 , oropharynx in 1 , larynx in 1 , pancreas in 1 , and melanoma in 1). Nine patients died from cardiovascular disease, two from pneumonia, and one from trauma. Latent membrane proteinl expression was observed in 6 (24\%) of these 25 patients, and only 1 of them died from the disease. None of the investigated clinical and pathological

TABLE 3. Correlation Analysis of Clinical Parameters of Patients with Known EBV Status

\begin{tabular}{lllc}
\hline Parameter & EBV + n (\%) & EBV-n (\%) & $P$-value \\
\hline Sex & & & \\
$\quad$ Male & $20 / 65(31 \%)$ & $45 / 65(69 \%)$ & .2 \\
$\quad$ Female & $11 / 54(20 \%)$ & $43 / 54(80 \%)$ & \\
Age & & & \\
$\quad<45$ & $18 / 86(21 \%)$ & $68 / 86(79 \%)$ & .04 \\
$>45$ & $13 / 33(39 \%)$ & $20 / 33(61 \%)$ & \\
Stage & & & \\
I + II & $15 / 68(22 \%)$ & $53 / 68(78 \%)$ & .43 \\
III + IV & $14 / 42(33 \%)$ & $28 / 42(67 \%)$ & \\
B symptoms & & & .27 \\
Pos & $16 / 51(31 \%)$ & $35 / 51(69 \%)$ & \\
Neg & $13 / 59(22 \%)$ & $46 / 59(78 \%)$ & .26 \\
Risk factors & & & \\
Pos & $15 / 49(31 \%)$ & $34 / 49(69 \%)$ & \\
Neg & $12 / 57(21 \%)$ & $45 / 57(79 \%)$ & \\
\hline
\end{tabular}

parameters, including EBV status, showed a significant influence on overall survival (Fig. 4; Table 3).

\section{DISCUSSION}

The present large single-center study from Austria demonstrates a low prevalence of EBV positivity of $26 \%$ in classical Hodgkin's lymphoma. EBV positivity is associated with a higher clinical stage and age as well as with mixed-cellularity subtype. Overall and failure-free survival did not differ significantly between EBV-positive and -negative cases, but a significantly shorter time to relapse was observed for EBV-negative cases $(P<.02)$. This analysis of 119 classical Hodgkin's lymphoma cases confirms the data from eastern and western Europe, with EBV positivity in $26 \%$ of the Croatian and $27 \%$ of British patients and with increasing rates for patients older than 45 years of age $(22,24,37,38)$. The reasons for the significantly lower rate of EBVassociated classical Hodgkin's lymphoma in European and Western world populations, in contrast to the case of those in developing countries, are enigmatic and complex. One could speculate that the lower socioeconomic status in underdeveloped countries could be responsible for chronic immunosuppression attributable to malnutrition, a concept that could explain the marked increase of EBV infection in the pediatric population in these countries $(4,5)$. Chronic immunosuppression due to autoimmune disorders, human immunodeficiency virus infection, or posttransplantation status is also correlated with increased EBV infection and classical Hodgkin's lymphoma (39-41). However, various predisposing conditions and to-date-unknown possible interactions between virus and host seem to be responsible for the geographically different association rates of EBV and classical Hodgkin's lymphoma.

Irrespective of the underlying causes for the variability of EBV association, recent studies investigated the potential prognostic importance of EBV in classical Hodgkin's lymphoma. Whereas earlier, small studies failed to demonstrate any significant impact, more recent studies of larger series of patients provided evidence for a beneficial effect of EBV positivity. Montalban et al. (18) and Morente and coworkers (21) reported a better overall survival and a higher rate of complete remission and failure-free survival for EBV-associated classical Hodgkin's lymphoma in a Spanish population. In agreement with these results from Spain, three studies from Great Britain, Croatia, and India demonstrated a significantly longer failure-free survival in EBV-associated classical Hodgkin's lymphoma, but no correlation for overall survival was observed $(17,21-23)$. Our results, with an 


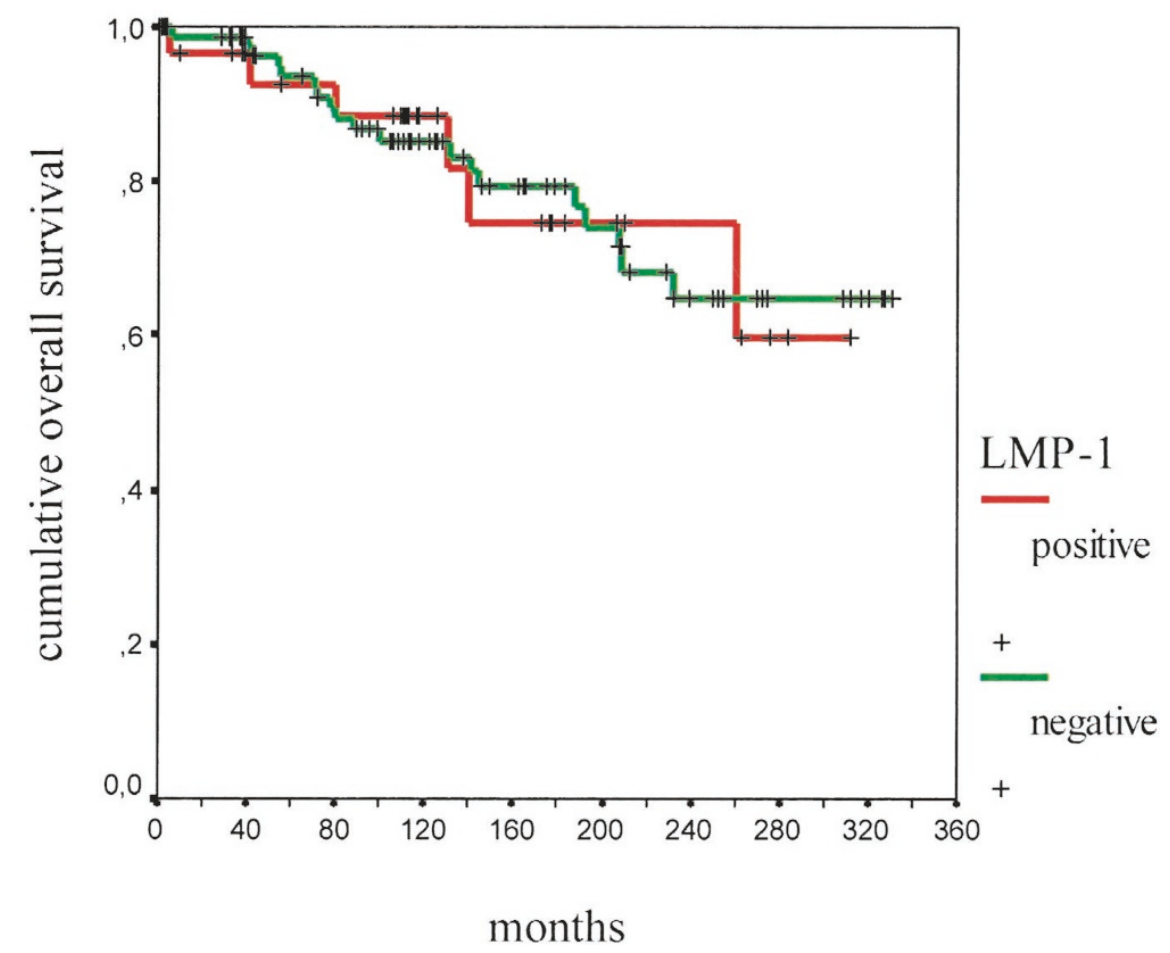

FIGURE 3. Overall survival and latent membrane proteinl expression in classical Hodgkin's lymphoma. No significant differences between the groups as compared by the log-rank test $(P<.92)$.

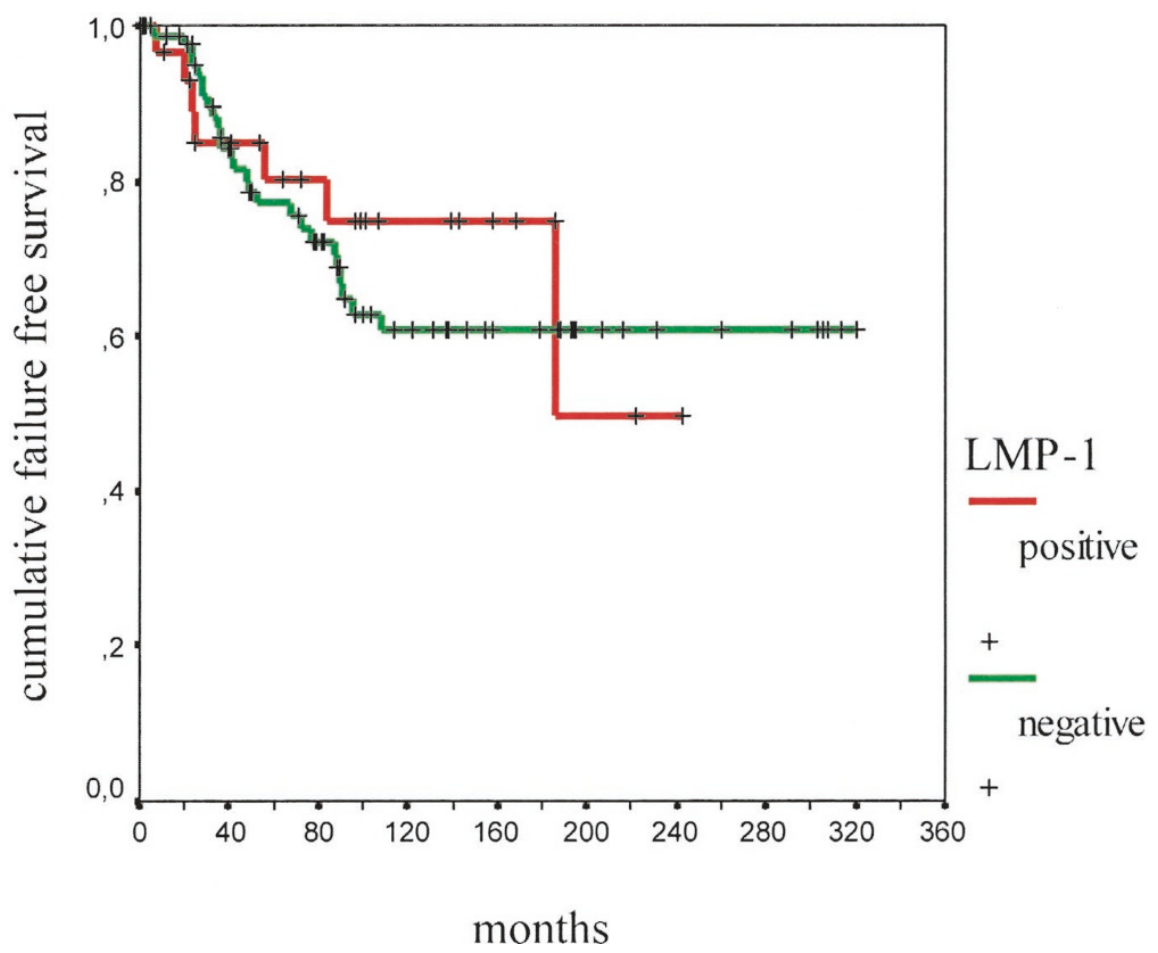

FIGURE 4. Failure-free survival and latent membrane proteinl expression in classical Hodgkin's lymphoma. No significant differences between the groups as compared by the log-rank test $(P<.53)$. However, note significantly later first recurrences in the latent membrane protein1-expressing group $(P<.02$ as compared by the Spearman rank test).

increased failure-free survival interval of 99 months for EBV-positive patients, compared with 49 months for EBV-negative classical Hodgkin's lymphoma $(P<.02)$, are in perfect agreement with those findings.
A positive interaction between EBV-infected Hodgkin and Reed-Sternberg cells and chemotherapeutic agents via apoptosis induced by BCL2 overexpression in EBV-negative, but lack of BCL2 expression in EBV-positive, Hodgkin and Reed- 
Sternberg cells could explain the longer failure-free survival (42). Furthermore, residual EBV-positive tumor cells after cytoreduction by chemotherapy could be the target for immune cytolysis. This has implications for a potential development of specific immunotherapy. Some investigators obtained more activated cytotoxic T-lymphocytes and found increased levels of major histocompatibility complex Class I expression in Hodgkin and Reed-Sternberg cells in EBV-associated classical Hodgkin's lymphoma cases, compared with in EBV-negative cases (43-45).

Regarding the configuration of the latent membrane protein 1 gene, we found the characteristic 30 -base pair in frame gene deletion in only $13 \%$ of the cases of classical Hodgkin's lymphoma in Austria. The low prevalence of this variant is in agreement with that found in other Western populations, apart from a childhood series from Spain (27, 28, 46-49). The even higher prevalence of the latent membrane protein1 deletion in reactive lymphoid tissues from the same geographic region argues against a more potent tumor-promoting activity of this variant and confirms and extends our recent findings in a Mexican population. It is noteworthy that although the number of cases with latent membrane protein1 gene deletion is too low for firm conclusions, we did not find a decreased failurefree or overall survival compared with the case of EBV-associated cases without the gene deletion.

The high prevalence of EBV Type A in this series, which is the common virus strain in European countries, both in classical Hodgkin's lymphoma $(100 \%)$ and in reactive lymphoid tissue (93\%), is in contrast with an increased occurrence of Type B in our previous Mexican series, thereby underlining the importance of geographical factors $(47,49)$.

In summary, our study of classical Hodgkin's lymphoma revealed a statistically significantly longer failure-free survival interval of EBV-positive classical Hodgkin's lymphoma. The low prevalence of EBV infection in classical Hodgkin's lymphoma from Austria $(26 \%)$, the exclusive infection with Subtype A virus strain (100\%), and the similar distribution of the latent membrane protein 1 deletion variant in neoplastic (13\%) and reactive lymphoid cells (37\%) highlights the paramount importance of geographical and/or ethnic factors in EBVassociated classical Hodgkin's lymphoma. Finally, increased oncogenic potential of the latent membrane protein1 deletion variant is unlikely.

\section{REFERENCES}

1. Brooks L, Thomas JA. The significance of Epstein Barr virus in the pathogenesis of lymphoid and epithelial neoplasia. Curr Diag Pathol 1995;2:163-74.

2. Anagnostopoulos I, Hummel M. Epstein-Barr virus in tumours. Histopathology 1996;29:297-315.
3. Weinreb M, Day PJR, Niggli F, Green EK, Nyongò AO, Othieno-Abinya NA, et al. The consistent association between Epstein-Barr virus and Hodgkin's disease in children in Kenya. Blood 1996;87:3828-36.

4. Chang KL, Albujar PF, Chen YY, Johnson RM, Weiss LM. High prevalence of Epstein-Barr virus in the Reed-Sternberg cells of Hodgkin's disease occurring in Peru. Blood 1993;81: 496-501.

5. Quintanilla-Martinez L, Gamboa-Dominquez A, GamezLedesma I, Angeles-Angeles A, Mohar A. Association of Epstein-Barr virus latent membrane protein and Hodgkin's disease in Mexico. Mod Pathol 1995;8:675-9.

6. Dirnhofer S, Angeles-Angeles A, Ortiz-Hidalgo C, Reyes E, Gredler E, Krugmann J, et al. High prevalence of a 30-base pair deletion in the Epstein-Barr virus (EBV) latent membrane protein 1 gene and of strain type B EBV in Mexican classical Hodgkin's disease and reactive lymphoid tissue. Hum Pathol 1999;30:781-7.

7. Weiss LM. Epstein-Barr virus and Hodgkin's disease. Curr Oncol Rep 2000;2:199-204.

8. Spieker T, Kurth J, Küppers R, Rajewsky K, Bräuninger A, Hansmann ML. Molecular single-cell analysis of the clonal relationship of small Epstein-Barr virus-infected cells and Epstein-Barr virus-harboring Hodgkin and Reed-Sternberg cells in Hodgkin's disease. Blood 2000;96:3133-8.

9. Flavell KJ, Murray PG. Hodgkin's disease and the EpsteinBarr virus. Mol Pathol 2000;53:262-9.

10. Gulley ML. Molecular diagnosis of Epstein-Barr virus-related diseases. J Mol Diagn 2001;3:1-10.

11. Kandil A, Bazarbashi S, Mourad WA. The correlation of Epstein-Barr virus expression and lymphocyte subsets with the clinical presentation of nodular sclerosing Hodgkin disease. Cancer 2001;91:1957-63.

12. Flavell KJ, Biddulph JP, Powell JE, Parkes SE, Redfern D, Weinreb M, et al. South Asian ethnicity and material deprivation increase the risk of Epstein-Barr virus infection in childhood Hodgkin's disease. Br J Cancer 2001;85:350-6.

13. Engel M, Essop MF, Close P, Hartley P, Pallesen G, SinclairSmith C. Improved prognosis of Epstein-Barr virus-associated childhood Hodgkin's lymphoma: study of 47 South African cases. J Clin Pathol 2000;53:182-6.

14. Macak J, Habanec B, Fabian P. Detection of Epstein-Barr virus in Hodgkin's lymphoma. Neoplasma 2000;47:156-61.

15. Zhou XG, Sandvej K, Li PJ, Ji XL, Yan QH, Zhang XP, et al. Epstein-Barr virus (EBV) in Chinese pediatric Hodgkin's disease. Hodgkin disease in young children is an EBV-related lymphoma. Cancer 2001;92:1621-31.

16. Khan G, Norton AJ, Slavin G. Epstein-Barr virus in Hodgkin disease. Relation to age and subtype. Cancer 1993;71:3124-9.

17. Naresh KN, Johnson J, Srinivas V, Soman CS, Saikia T, Advani $\mathrm{SH}$, et al. Epstein-Barr virus association in classical Hodgkin's disease provides survival advantage to patients and correlates with higher expression of proliferation markers in Reed-Sternberg cells. Ann Oncol 2000;11:91-6.

18. Montalban C, Abraira V, Morente M, Acevedo A, Aguilera B, Bellas C, et al. Epstein-Barr virus latent membrane protein 1 expression has a favorable influence in the outcome of patients with Hodgkin's disease treated with chemotherapy. Leuk Lymphoma 2000;39:563-72.

19. Vestlev PM, Pallesen G, Sandviej K, Hamilton-Dutoit SJ, Bendtzen SM. Prognosis of Hodgkin's disease is not influenced by Epstein-Barr virus latent membrane protein. Int J Cancer 1992;50:670-1.

20. Oudejans JJ, Jiwa NM, Meijer CJLM. Epstein-Barr virus in Hodgkin's disease: more than just an innocent bystander. J Pathol 1997;181:353-6.

21. Morente M, Piris MA, Abraira V, Acevedo A, Aguilera B, Bellas C, et al. Adverse clinical outcome in Hodgkin's disease is associated with loss of retinoblastoma protein expression, 
high Ki67 proliferation index and absence of Epstein-Barr virus latent membrane protein 1 expression. Blood 1997;90: 2429-36.

22. Murray PG, Billingham LJ, Hassan HT, Flavell JR, Nelson PN, Scott K, et al. Effect of Epstein-Barr virus infection on response to chemotherapy and survival in Hodgkin's disease. Blood 1999;94:442-7.

23. Clarke CA, Glaser SL, Dorfman RF, Mann R, Di Giuseppe JA, Prehn AW, et al. Epstein-Barr virus and survival after Hodgkin's disease in a population-based series of women. Cancer 2001;91:1579-87.

24. Glavina-Durdov M, Jakic-Razumovic J, Capkun V, Murray P. Assessment of the prognostic impact of the Epstein-Barr virus-encoded latent membrane protein-1 expression in Hodgkin's disease. Br J Cancer 2001;84:1227-34.

25. Kieff E, Liebowitz D. Epstein-Barr virus and its replication. In: Fields BN, Knipe DM, editors. Virology. 2nd ed. New York: Raven; 1990. p. 1889-920.

26. Kaye KM, Izumi KM, Kieff E. Epstein-Barr virus latent membrane protein 1 is essential for B-lymphocyte growth transformation. Proc Natl Acad Sci U S A 1993;90:9150-4.

27. Knecht H, Bachmann E, Brousset P, Sandvej K, Nadal D, Bachmann F, et al. Deletions within the LMP-1 oncogene of Epstein-Barr virus are clustered in Hodgkin's disease and identical to those observed in nasopharyngeal carcinoma. Blood 1993;82:2937-42.

28. Hayashi K, Chen WG, Chen YY, Bacchi MM, Bacchi CE, Alvarenga $\mathrm{M}$, et al. Deletion of Epstein-Barr virus latent membrane protein 1 gene in United States and Brazilian Hodgkin's disease and reactive lymphoid tissue: high frequency of a 30-bp deletion. Hum Pathol 1997;28:1408-14.

29. Leung SY, Yuen ST, Chung LP, Chan ASY, Wong MP. Prevalence of mutations and 30-bp deletion in the C-terminal region of Epstein-Barr virus latent membrane protein-1 oncogene in reactive lymphoid tissue and non-nasopharyngeal EBV-associated carcinomas in Hong Kong Chinese. Int J Cancer 1997;72:225-30.

30. Harris NL, Jaffe ES, Diebold J, Flandrin G, Müller-Hermelink HK, Vardiman J, et al. World Health Organization classification of neoplastic diseases of the hematopoietic and lymphoid tissues: J Clin Oncol 1999;17:3835-49.

31. Fend F, Hittmair A, Rogatsch H, Gredler E, Obrist P, Mikuz G. Seminomas positive for Epstein-Barr virus by the polymerase chain reaction: viral RNA transcripts (Epstein-Barrencoded small RNAs) are present in intratumoral lymphocytes but absent from neoplastic cells. Mod Pathol 1995;8: 622-5.

32. Vasef MA, Kamel OW, Chen YY, Medeiros LJ, Weiss LM. Detection of Epstein-Barr virus in multiple sites involved by Hodgkin's disease. Am J Pathol 1995;147:1408-15.

33. Saiki RK, Bugawan TL, Horn GT, Mullis KB, Erlich HA. Analysis of enzymatically amplified $\beta$-globin and HLA-DQ $\alpha$ DNA with allele-specific oligonucleotide probes. Nature 1986;324: 487-91.

34. Lin JC, Lin SC, De BK, Chan WP, Evatt BL. Precision of genotyping of Epstein-Barr virus by polymerase chain reaction using three gene loci (EBNA-2, EBNA-3C, and EBER): predominance of type A virus associated with Hodgkin's disease. Blood 1993;81:3372-81.

35. Kaplan EL, Meier P. Nonparametric estimation from incomplete observation. J Am Stat Assoc 1958;53:457-81.

36. Petö R, Pike MC, Armitage P, Breslow NE, Cox DR, Howard $\mathrm{SU}$, et al. Design and analysis of randomized clinical trials requiring prolonged observation of each patient. II. Analysis and examples. Br J Cancer 1977;39:1-39.

37. Glaser SL, Lin RJ, Stewart SL, Ambinder RF, Jarrett RF, Brousset $\mathrm{P}$, et al. Epstein-Barr virus-associated Hodgkin's disease. Epidemiologic characteristics in international data. Int $\mathrm{J}$ Cancer 1997;70:375-82.

38. Ambinder RF, Browning PJ, Lorenzana I, Leventhal BG, Cosenza H, Mann RB, et al. Epstein-Barr virus and childhood Hodgkin's disease in Honduras and in United States. Blood 1993;81:462-7.

39. Kamel OW, van de Rijn M, LeBrun DP, Weiss LM, Warnke RA, Dorfman RF. Lymphoid neoplasms in patients with rheumatoid arthritis and dermatomyositis: frequency of Epstein-Barr virus and other features associated with immunosuppression. Hum Pathol 1994;25:638-43.

40. Herndier BG, Sanchez HC, Chang KL, Chen YY, Weiss LM. High prevalence of Epstein-Barr virus in the Reed-Sternberg cells of HIV-associated Hodgkin's disease. Am J Pathol 1993; 142:1073-9.

41. Knowles DM, Chamulak GA, Subar M, Burke JS, Dugan M, Wernz J, et al. Lymphoid neoplasia associated with the acquired immunodeficiency syndrome (AIDS): the New York University Medical Center experience with 105 patients (1981-1986). Ann Intern Med 1988;108:744-53.

42. Jiwa NM, Oudejans JJ, Bai MC, van den Brule AJ, Horstman A, Vos W, et al. Expression of bcl-2 protein and transcription of the Epstein-Barr virus homologue BHRF-1 in Hodgkin's disease: implications for different pathogenic mechanisms. Histopathology 1995;26:547-53.

43. Oudejans JJ, Jiwa NM, Kummer JA, Horstman A, Vos W, Baak JP, et al. Analysis of major histocompatibility complex class I expression on Reed-Sternberg cells in relation to the cytotoxic T-cell response in Epstein-Barr virus-positive andnegative Hodgkin's disease. Blood 1996;87:3844-51.

44. Lee SP, Constandinou CM, Thomas WA, Croom-Carter D, Blake NW, Murray PG, et al. Antigen presenting phenotype of Hodgkin Reed-Sternberg cells: analysis of the HLA class I processing pathway and the effects of interleukin-10 on Epstein-Barr virus-specific cytotoxic T-cell recognition. Blood 1998;92:1020-30.

45. Murray PG, Constandinou CM, Crocker J, Young LS, Ambinder RF. Analysis of major histocompatibility complex class I, TAP expression, and LMP2 epitope sequence in Epstein-Barr virus-positive Hodgkin's disease. Blood 1998; 92:2477-83.

46. Chen WG, Chen YY, Bacchi MM, Bacchi CE, Alvarenga M, Weiss LM. Genotyping of Epstein-Barr virus in Brazilian Burkitt's lymphoma and reactive lymphoid tissue. Am J Pathol 1996;148:17-23.

47. Hirose Y, Masaki Y, Kurose N. Frequency of the 30-base pair deletion in the latent membrane protein-1 gene in EpsteinBarr virus-associated lymphomas in Japan. Int J Hematol 2000;72:210-5.

48. Santon A, Martin C, Manzanal AI, Preciado MV, Bellas C. Paediatric Hodgkin's disease in Spain. Association with Epstein-Barr virus strains carrying latent membrane protein-1 oncogene deletion and high frequency of dual infections. Br J Haematol 1998;103:129-36.

49. Frank D, Cesarman E, Liu YF, Michler RE, Knowles DM. Posttransplantation lymphoproliferative disorders frequently contain type A and not type B Epstein-Barr virus. Blood 1995;85:1396-403. 